\title{
Kadar Kolesterol Total dan Tekanan Darah Orang Dewasa Indonesia
}

\section{Total Cholesterol and Blood Pressure Among Indonesian Adults}

\author{
Yohana Margarita* Princen* Andi* Marcella Erwina Rumawas* Valentinus Budi Kidarsa* Bambang Sutrisna**
}

\author{
*Fakultas Kedokteran Universitas Tarumanegara Jakarta, **Departemen Epidemiologi Fakultas Kesehatan \\ Masyarakat Universitas Indonesia
}

\begin{abstract}
Abstrak
Penelitian dengan desain potong lintang ini bertujuan untuk menguji hubungan antara kadar kolesterol total dengan tekanan darah. Data dikumpulkan pada 14 - 21 Juni 2011, terhadap 51 subjek penelitian berusia $>30$ tahun yang tidak mengonsumsi obat antihipertensi ataupun antikolesterol, dipilih secara consecutive antara pengunjung Puskesmas Kelurahan Joglo-II, Jakarta. Tekanan darah diukur dengan sfigmomanometer sesuai pedoman baku. Kadar kolesterol total darah sewaktu diukur dari sampel darah tepi dengan alat tes kolesterol. Analisis data menggunakan regresi linier, korelasi Pearson dan General Linear Model dengan koreksi Bonferroni. Pada 51 responden (nilai tengah usia 50 tahun, $70,6 \%$ perempuan), rerata kadar kolesterol total adalah $200 \mathrm{mg} / \mathrm{dL}$ dan rerata tekanan darah adalah 135/84 $\mathrm{mmHg}$. Pada faktor perancu yang disetarakan, kadar kolesterol total yang tinggi berhubungan dengan tingginya tekanan darah sistolik $(r=0,39$; nilai $p=0,005)$ ataupun diastolik $(r=0,43$; nilai $p=0,002)$. Responden pada kelompok kuartil ketiga total kolesterol memiliki tekanan darah $26 / 11 \mathrm{mmHg}$ lebih tinggi secara bermakna dibandingkan mereka pada kelompok kuartil kedua (nilai $p=0,001$ dan nilai $p=0,002$ berturut-turut untuk tekanan darah sistolik dan diastolik). Menjaga kadar kolesterol total dalam batas normal merupakan salah satu upaya untuk mencegah hipertensi.
\end{abstract}

Kata kunci: Kadar kolesterol total, tekanan darah, hipertensi

\footnotetext{
Abstract

This cross-sectional study was aimed to examine the association between total cholesterol levels and blood pressures. Data was collected on June $14-21,2011$, among 51 subjects, aged $>30$ years, who were taking neither antihypertensive nor anticholesterol drug, consecutively selected among peoples attending Joglo-II Sub-district Primary Health Center, Jakarta. Blood pressures were measured using a manual sphygmomanometer according to the standard protocols. Peripheral blood samples were collected and non-fasting total cholesterol were assessed using a cholesterol-test kit. Analyses were perfomed using linear regression, Pearson
}

correlation, and General Linear Model (with Bonferroni correction). In 51 respondents (median age 50 years, $70.6 \%$ female), mean total cholesterol level was $200 \mathrm{mg} / \mathrm{dL}$ and blood pressure were 135/84 mmHg. After adjustment for confounding factors, higher total cholesterol levels were associated with higher systolic $(r=0.39$; $p$ value $=0.005)$ or diastolic $(r=0.43$; $p$ value $=0.002$ ) blood pressures. Participant in the third quartile category had blood pressures $26 / 11 \mathrm{mmHg}$ significantly higher than that of those in the second quartile category ( $p$ value $=0,001$ and $p$ value $=0,002$ for sistolic and diastolic blood pressures, respectively). Maintaining total cholesterol levels within the normal limits may be one way to prevent hypertension.

Keywords: Total cholesterol, blood pressure, hypertension

\section{Pendahuluan}

Hipertensi adalah salah satu penyakit yang umum melanda di dunia dan merupakan faktor risiko penting untuk penyakit jantung serta kontributor utama mortalitas dan morbiditas baik di negara maju maupun di negara berkembang. ${ }^{1}$ Menurut laporan kesehatan dunia, pada tahun 2002, sekitar 600 juta orang di seluruh dunia menderita hipertensi. Hipertensi diperkirakan menyebabkan 7,1 juta kematian setiap tahunnya, angka tersebut mewakili sekitar $13 \%$ dari total kematian. ${ }^{2}$ Di berbagai negara di Asia, prevalensi hipertensi bervariasi, berkisar antara $15-35 \%$. Angka tersebut diperkirakan akan terus meningkat setiap tahunnya. ${ }^{3}$ Misalnya, prevalensi hipertensi di Vietnam pada tahun 2002 sebesar 14,1\% dan hipertensi juga merupakan penyakit yang menyebabkan sejumlah besar kematian di rumah sakit. ${ }^{2}$

Alamat Korespondensi: Marcella Erwina Rumawas, Fakultas Kedokteran Universitas Tarumanegara, Jl. Letnan Jenderal S. Parman No. 1 Grogol Jakarta Barat 11440, Hp.081280979353,e-mail: marcellarumawas@gmail.com 
Hipertensi merupakan penyebab kematian nomor tiga setelah stroke dan tuberkulosis, yakni mencapai 6,7\% kematian pada semua umur di Indonesia. ${ }^{4}$ Data Riskesdas 2007 menyebutkan prevalensi hipertensi di Indonesia berkisar 30\% dengan insiden komplikasi penyakit kardiovaskular lebih banyak pada perempuan $(52 \%)$ dibandingkan laki-laki $(48 \%) .{ }^{5}$ Oleh karena dampaknya yang berhubungan dengan morbiditas dan mortalitas, maka hipertensi merupakan tantangan bagi kesehatan masyarakat. Di Puskesmas Kelurahan Joglo II, berdasarkan data tahun 2010, terdapat 565 kasus hipertensi dari 15.342 kunjungan sakit, dengan usia tersering penderita antara 40 - 70 tahun. Angka ini menempatkan hipertensi pada urutan terbanyak ketiga setelah ISPA dan mialgia. Berdasarkan hasil wawancara dengan beberapa petugas Puskesmas Kelurahan Joglo II, banyak pasien yang tidak mengetahui dampak kadar kolesterol total terhadap tekanan darah karena tidak adanya fasilitas pemeriksaan kolesterol di Puskesmas Kelurahan Joglo II. Tujuan penelitian ini adalah untuk mengetahui adakah hubungan antara kadar kolesterol total dengan tekanan darah pada laki-laki dan perempuan berusia 30 tahun ke atas yang datang ke Puskesmas Kelurahan Joglo II Jakarta Barat. Dengan diketahuinya hubungan antara kadar kolesterol total dengan tekanan darah, diharapkan dapat menurunkan prevalensi hipertensi di wilayah kerja Puskesmas Kelurahan Joglo II.

\section{Metode}

Penelitian ini menggunakan desain studi analitik observasional potong lintang untuk mengetahui hubungan antara kadar kolesterol total dengan tekanan darah. Besar sampel minimal yang dibutuhkan dihitung dengan perkiraan koefisien korelasi antara kadar kolesterol total dengan tekanan darah minimum sebesar 0,7 ( $\alpha=5 \%$; $\alpha$ $=20 \%$ ). Sampel penelitian dipilih secara consecutive non-random sampling diantara 196 pengunjung Puskesmas Kelurahan Joglo II pada tanggal 14 - 21 Juni 2011 yang berusia $>30$ tahun, tidak mengonsumsi obat penurun kolesterol serta tidak mengonsumsi obat anti hipertensi.

Kadar kolesterol total sewaktu diukur dengan digital stik tes kolesterol. Pengukuran diawali dengan tindakan antisepsis pada salah satu ujung jari pasien, selanjutnya dilakukan tusukan dengan jarum, darah yang keluar kemudian diletakkan pada strip yang telah dipasang pada alat tes kolesterol. Setelah 150 detik hasil dapat dibaca. Pengukuran tekanan darah dilakukan saat pasien dalam keadaan tenang dan setelah duduk minimal 5 menit. Posisi lengan kanan yang akan diperiksa dan sfigmomanometer sejajar dengan tinggi jantung. Manset dipasang $3 \mathrm{~cm}$ di atas lipat siku kemudian dikembangkan. Bunyi Korotkoff pertama menunjukkan tekanan darah sistolik sedangkan bunyi Korotkoff kelima (bunyi ter- akhir yang didengar pemeriksa) menunjukkan tekanan darah diastolik. Pengukuran dilakukan dua kali berjarak dua menit dan nilai rata-rata kedua pengukuran tersebut dihitung.

Data usia dan jenis kelamin dikumpulkan dengan metode wawancara menggunakan kuesioner terstruktur. Berat badan dan tinggi badan diukur dalam posisi berdiri tegak tanpa mengenakan alas kaki. Berat badan diukur dengan timbangan berat badan manual. Tinggi badan (dalam meter) diukur dengan menggunakan pengukur tinggi badan. Indeks massa tubuh (IMT) dihitung sebagai berat badan dibagi tinggi badan (pangkat dua) $\left(\mathrm{kg} / \mathrm{m}^{2}\right.$ ).

Kadar kolesterol total $(\mathrm{mg} / \mathrm{dL}$ ) adalah variabel bebas dan tekanan darah sistolik dan diastolik $(\mathrm{mmHg})$ adalah variabel tergantung. Distribusi data kadar kolesterol total relatif nomal namun distribusi tekanan darah sistolik maupun diastolik tidak normal. Untuk mendapatkan distribusi data normal, dilakukan transformasi logaritmik terhadap data tekanan darah sistolik maupun diastolik. Rata-rata geometrik dihitung sebagai eksponen nilai dalam skala logaritmik, untuk menyatakan tekanan darah sistolik ataupun diastolik dalam skala yang sesungguhnya.

Data kadar kolesterol total dan tekanan darah analisis dalam skala numerik dan juga dalam skala kategorik dengan membagi data kadar kolesterol total tersebut menjadi empat subkategori berdasarkan nilai kuartil. Data tekanan sistolik dan diastolik dianalisis dalam skala numerik. Analisis primer yang bertujuan untuk menguji asosiasi linier antara kadar kolesterol total dan tekanan darah sistolik atau diastolik dilakukan dengan menerapkan uji statistik korelasi Pearson dan regresi linier. Analisa sekunder yang bertujuan untuk mengetahui berapa perbedaan rerata tekanan sistolik atau diastolik antara kuartil kategori ke-2, ke-3, dan ke-4 dengan kuartil kategori pertama kadar kolesterol total, dilakukan dengan menerapkan uji statistik univariate General Linear Model (GLM) dengan koreksi Bonferroni untuk multiple comparison.

Faktor-faktor perancu potensial yang dianalisis adalah usia (tahun), jenis kelamin (perempuan/laki-laki) dan IMT $\left(\mathrm{kg} / \mathrm{m}^{2}\right)$. Pengaruh faktor perancu potensial diuji berdasarkan metode analysis of covariance dengan menggunakan prosedur univariate GLM. Nilai $\mathrm{p}<0,05$ dinyatakan sebagai adanya hubungan asosiasi statistik yang bermakna.

\section{Hasil}

Dari 51 responden berusia 30 tahun ke atas yang datang ke Puskesmas Kelurahan Joglo II Jakarta Barat selama periode penelitian (14 - 21 Juni 2011), didapatkan $29,4 \%$ laki-laki dan $70,6 \%$ perempuan. Pada 51 responden tersebut nilai tengah (minimum; maksimum) usia dan IMT berturut-turut adalah $50(33 ; 74)$ dan 24,9 
Tabel 1. Karakteristik Responden

\begin{tabular}{|c|c|c|c|c|}
\hline \multirow{2}{*}{ Kategori } & \multicolumn{4}{|c|}{ Kelompok Kuartil Kadar Kolesterol Total } \\
\hline & Q1 & Q2 & Q3 & Q4 \\
\hline $\mathrm{n}$ & 12 & 13 & 13 & 13 \\
\hline Kadar kolesterol total $(\mathrm{mg} / \mathrm{dL})^{*}$ & $164(113-172)$ & $186(173 \mathrm{c} 199)$ & $214(200-222)$ & $226(223-300)$ \\
\hline Usia (tahun) ${ }^{\dagger}$ & $45(35 ; 62)$ & $48(33 ; 62)$ & $58(36 ; 63)$ & $50(39 ; 74)$ \\
\hline Perempuan $(\%) \ddagger$ & $10(83,3)$ & $9(69,2)$ & $7(53,8)$ & $10(76,9)$ \\
\hline IMT $\left(\mathrm{kg} / \mathrm{m}^{2}\right) \dagger$ & $23,1(18,9 ; 32,9)$ & $24,9(17,0 ; 29,1)$ & $25,2(19,4 ; 35,9)$ & $25,8(16,8 ; 32,9)$ \\
\hline
\end{tabular}

Keterangan :

* Nilai tengah (rentang)

$\dagger$ Nilai tengah (minimum; maksimum)

$\doteqdot$ Nilai jumlah (persentase)

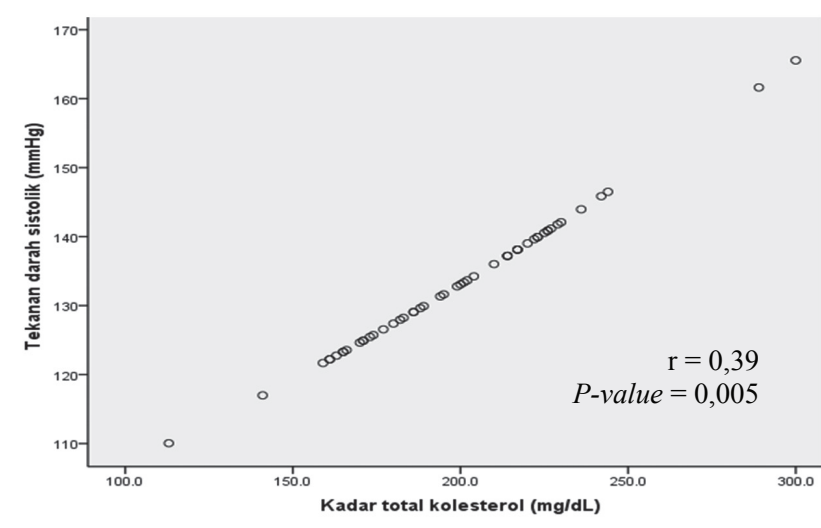

Gambar 1. Asosiasi Linier Antara Kadar Kolesterol Total dengan Tekanan Darah Sistolik pada Usia, Jenis Kelamin, dan IMT yang Disetarakan

$(16,8 ; 35,9)$. Kadar kolesterol total darah dibagi dalam empat kategori berdasarkan jumlahnya, dengan nilai tengah pada masing-masing kelompok berkisar antara 164 - $226 \mathrm{mg} / \mathrm{dL}$ (Tabel 1). Didapatkan 12 responden $(23,5 \%)$ memiliki nilai kadar kolesterol total $<173$ $\mathrm{mg} / \mathrm{dL} ; 13$ responden $(25,5 \%)$ memiliki nilai kadar kolesterol total $173-199 \mathrm{mg} / \mathrm{dL} ; 13$ responden $(25,5 \%)$ memiliki nilai kadar kolesterol total $200-222 \mathrm{mg} / \mathrm{dL}$; dan 13 responden $(25,5 \%)$ memiliki nilai kadar kolesterol total $\geq 223 \mathrm{mg} / \mathrm{dL}$. Pada 51 responden, dibandingkan dengan responden di kelompok kuartil lainnya, usia responden pada kelompok kuartil ketiga kadar kolesterol total lebih tua; lebih banyak responden perempuan daripada laki-laki pada kelompok kuartil pertama dan keempat; dan nilai tengah IMT yang lebih tinggi pada responden di kelompok kuartil keempat.

Pada 51 responden, didapatkan rata-rata (persentil 5; 95) kadar kolesterol total sebesar 199 (152; 262), sementara rata-rata geometrik tekanan darah sistolik dan diastolik berturut-turut adalah $133(100 ; 181) \mathrm{mmHg}$ dan 83 $(70 ; 100) \mathrm{mmHg}$. Terdapat hubungan statistik bermakna antara kadar kolesterol total dan tekanan darah sistolik atau diastolik (nilai $\mathrm{p}=0,005$ dan nilai $\mathrm{p}=0,002$, secara

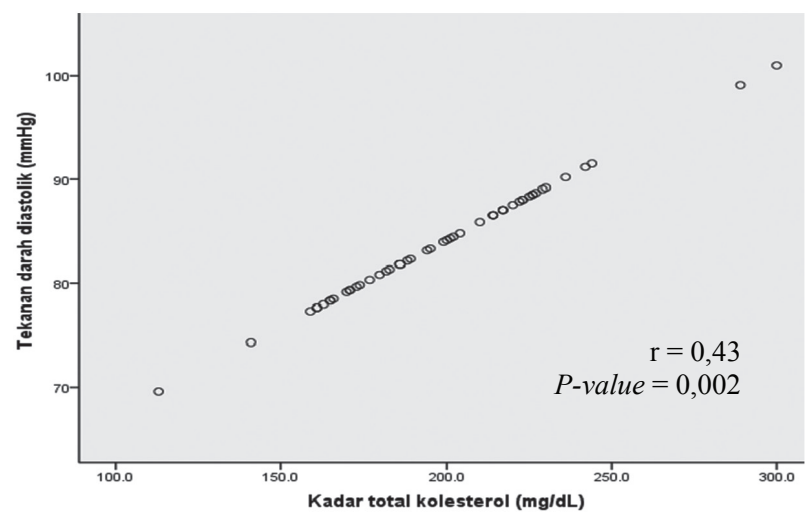

Gambar 2. Asosiasi Linier Antara Kadar Kolesterol Total dengan Tekanan Darah Diastolik pada Usia, Jenis Kelamin, dan IMT yang Disetarakan

berurutan), dengan asosiasi searah dan kekuatan hubungan lemah untuk tekanan sistolik dan sedang untuk tekanan diastolik. Hubungan ini tetap bermakna setelah faktor usia, jenis kelamin dan IMT disetarakan (nilai $\mathrm{p}=$ 0,000 dan nilai $\mathrm{p}=0,000$ ) (Gambar 1 dan 2).

Analisis sekunder (Tabel 2) dilakukan untuk mengetahui perbedaan rerata (interval kepercayaan sebesar 95\%) tekanan darah sistolik ataupun diastolik pada masing-masing kelompok kuartil kadar kolesterol total. Didapatkan perbedaan statistik yang bermakna rerata tekanan darah sistolik ataupun diastolik pada keempat kuartil kadar kolesterol total (nilai $\mathrm{p}=0,001$ untuk tekanan darah sistolik dan nilai $\mathrm{p}=0,002$ untuk tekanan darah diastolik). Penambahan faktor-faktor perancu potensial usia, jenis kelamin dan IMT tidak mempengaruhi hasil yang didapatkan (nilai $p=0,000$ dan nilai $p=0,000$ untuk tekanan darah sistolik dan diastolik secara berurutan). Hasil analisis lebih lanjut dengan koreksi Bonferroni menunjukkan bahwa pada faktor umur, jenis kelamin dan IMT yang disetarakan, terdapat perbedaan bermakna secara statistik pada rerata tekanan darah sistolik sebesar $26 \mathrm{mmHg}$ (nilai $\mathrm{p}=0,01$ ) ataupun tekanan darah diastolik sebesar $11 \mathrm{mmHg}$ (nilai $\mathrm{p}=0,04$ ) antara 
Tabel 2. Distribusi Tekanan Darah Sistolik dan Diastolik Menurut Kelompok Kuartil Kadar Kolesterol Total

\begin{tabular}{|c|c|c|c|c|c|c|}
\hline \multirow{2}{*}{ Tekanan Darah } & \multirow{2}{*}{ Model Statistik $^{\dagger}$} & \multicolumn{4}{|c|}{ Kelompok Kuartil Kadar Kolesterol Total } & \multirow{2}{*}{ Nilai $\mathrm{p}$} \\
\hline & & Q1 & Q2 & Q3 & Q4 & \\
\hline \multirow[t]{2}{*}{ Sistolik } & Model dasar & $127(115-140)^{\mathrm{ab}}$ & $116(105-126)^{\mathrm{a}}$ & $152(139-167)^{b}$ & $139(126-152)^{\mathrm{ab}}$ & 0,001 \\
\hline & Model 1 & $131(119-144)^{\mathrm{ab}}$ & $119(109-129)^{\mathrm{a}}$ & $145(132-158)^{b}$ & $137(125-150)^{\mathrm{ab}}$ & 0,000 \\
\hline \multirow[t]{2}{*}{ Diastolik } & Model dasar & $78(72-84)^{\mathrm{ab}}$ & $76(71-82)^{a}$ & $93(86-100)^{\mathrm{b}}$ & $86(80-93) a b$ & 0,002 \\
\hline & Model 1 & $79(74-86)^{\mathrm{ab}}$ & $78(80-83)^{\mathrm{a}}$ & $89(83-95)^{b}$ & $85(79-91)^{\mathrm{ab}}$ & 0,000 \\
\hline
\end{tabular}

Keterangan:

$\mathrm{Q} 1=<172,9 ; \mathrm{Q} 2=173-199,9 ; \mathrm{Q} 3=200-222,9 ; \mathrm{Q} 4=>223$

$\dagger$ Model dasar: kelompok kuartil kadar kolesterol total; Model 1: model dasar + usia, jenis kelamin dan IMT

$\mathrm{a}, \mathrm{b}$ Rerata geometrik dengan superskip yang tidak sama berbeda bermakna secara statistik ( $\mathrm{p}<0,05$ dengan koreksi Bonferroni); sebaliknya rerata geometrik dengan superskip yang sama tidak berbeda bermakna secara statistik $(p \geq 0,05$ dengan koreksi Bonferroni)

kelompok kuartil kedua dan ketiga kadar total kolesterol.

\section{Pembahasan}

Penelitian ini membuktikan hubungan antara kadar kolesterol total dengan tekanan darah sistolik dan diastolik. Ditemukan perbedaan bermakna rerata tekanan darah sistolik maupun diastolik pada keempat kelompok kuartil kadar kolesterol total (nilai $\mathrm{p}=0,001$ untuk tekanan darah sistolik dan nilai $\mathrm{p}=0,002$ untuk tekanan darah diastolik). Penambahan faktor perancu potensial seperti usia, jenis kelamin, IMT tidak mempengaruhi hubungan ini. Hasil tersebut sesuai dengan penelitian lain serupa yang telah dilakukan di pelbagai tempat di manca negara. Di Zaria, Nigeria Utara, penelitian yang membandingkan kadar kolesterol total serum pada 100 pasien hipertensi dengan 50 subjek normotensif dapatkan perbedaan statistik yang bermakna kadar kolesterol total serum pada pasien hipertensi $(198 \pm 4,64$ $\mathrm{mg} / \mathrm{dL}$ ) dibandingkan dengan subjek normotensif (174 \pm $4,25 \mathrm{mg} / \mathrm{dL}$ ). Kadar total kolesterol serum meningkat sesuai dengan peningkatan tekanan darah. Konsentrasi serum pada pasien hipertensi lebih tinggi daripada subjek normotensif mengindikasikan risiko terkena komplikasi kardiovaskular dan serebrovaskular yang lebih besar, seperti penyakit jantung koroner (PJK) dan stroke pada pasien hipertensi dengan kadar kolesterol tinggi. ${ }^{6}$

Sebuah studi di Iran di antara 250 penderita hipertensi dan 750 subjek sehat mendapatkan perbedaan statistik yang bermakna terhadap kadar kolesterol total dan risiko hipertensi (nilai $\mathrm{p}<0,001$ ). Selain itu, dengan menggunakan metode statistik kurva Receiver operating characteristic (ROC) didapatkan total kolesterol 185 $\mathrm{mg} / \mathrm{dL}$ sebagai nilai ambang batas yang optimal terhadap risiko hipertensi. ${ }^{7}$ Pan Junqiang, $\mathrm{dkk},{ }^{8}$ dalam sebuah penelitian yang melibatkan 1.114 subjek laki laki etnik Kazakh yang berusia di atas 30 tahun di Xinjiang mendapatkan bahwa tekanan darah meningkat sesuai dengan tingginya kadar kolesterol total darah, yang mana kadar kolesterol total pada subjek dengan hipertensi lebih tinggi secara bermakna daripada subjek normotensi.

Hubungan antara serum kolesterol dan tekanan darah juga diteliti di Oslo, Nowegia diantara sampel laki-laki yang berusia $20-49$. Hasil penelitian menunjukkan korelasi lemah $(\mathrm{r}=0,16$; nilai $\mathrm{p}<0,01)$ antara tekanan darah dan kolesterol serta didapatkan pada usia $40-49$ perbedaan kolesterol antara tekanan diastolik $<70$ $\mathrm{mmHg}$ dan $\geq 110 \mathrm{mmHg}$ adalah $27,4 \mathrm{mg} / \mathrm{dL} .{ }^{9}$ Penelitian di London dengan subjek penelitian sekitar 12,000 orang menunjukkan hubungan yang bermakna antara serum kolesterol dan tekanan darah sistolik maupun diastolik pada usia responden berusia $<65$ tahun. ${ }^{10}$ Penelitian Bulpitt, dkk yang dilakukan pada 698 subjek berusia 40 - 49 tahun menunjukkan asosiasi yang bermakna hanya antara tekanan darah sistolik yang dengan kolesterol serum (nilai $p=0,01) .11$ Sebuah kohort di North Karelia, Finlandia pada tahun 1972 - 1977 yang terdiri dari 293 laki-laki dan 321 perempuan yang tidak menggunakan obat antihipertensi melaporkan perubahan tekanan darah positif berkaitan dengan perubahan dalam serum kolesterol. ${ }^{12}$

Hasil penelitian ini juga sejalan dengan salah satu penelitian di Indonesia. Penelitian yang melibatkan 50 pasien hipertensi yang datang ke Puskesmas Sungai Besar Kota Banjar Baru menunjukkan hubungan statistik yang bermakna antara kadar kolesterol total dan hipertensi (nilai $\mathrm{p}=0,002$ ). Pada penelitian tersebut, responden dengan hipertensi tingkat 2 (takanan darah sistolik 160 $179 \mathrm{mmHg}$ ) dan tingkat 3 (tekanan darah sistolik >180) mayoritas terdapat pada kelompok responden dengan kadar kolesterol total antara $200-240 \mathrm{mg} / \mathrm{dL}$. Sementara responden dengan hipertensi tingkat 1 (tekanan sistolik $140-159 \mathrm{mmHg}$ ) mayoritas terdapat pada kelompok responden dengan kadar kolesterol total normal $(<$ $200 \mathrm{mg} / \mathrm{dL}) .{ }^{13}$ 
Hipertensi adalah kondisi umum yang memengaruhi banyak orang di dunia. Hipertensi berhubungan dengan abnormalitas lipid kolesterol total, dimana kehadiran dislipidemia meningkatkan risiko terjadinya hipertensi dan dengan demikian terjadi peningkatan risiko morbiditas dan mortalitas kardiovaskular. Meskipun beberapa faktor risiko hipertensi telah diidentifikasi, etiologi hipertensi masih belum sepenuhnya diketahui secara pasti. Banyak studi epidemiologik menunjukkan peningkatan progresif dalam risiko PJK dan hipertensi pada serum total kolesterol yang melebihi 193,2 mg/dL. Hiperkolesterolemia menyebabkan akumulasi partikel LDL di intima pembuluh darah. Partikel lipoprotein tersebut sering dihubungkan dengan konstituen matriks ekstraseluler. Sekuestrasi dalam intima memisahkan lipoprotein dari beberapa antioksidan plasma dan menyebabkan terjadinya modifikasi oksidatif. Partikel lipoprotein yang mengalami oksidasi tersebut dapat memicu respon inflamasi berupa ekspresi berbagai molekul adesi yang menyebabkan akumulasi monosit ke dalam lesi arterial. Sesaat setelah perlekatan terjadi, beberapa sel darah putih akan bermigrasi ke intima. Leukosit dalam fraksi lemak yang telah berevolusi dapat menunjukkan peningkatan ekspresi reseptor lipoprotein yang telah diubah (reseptor scavenger). Fagosit mononuklear ini mencerna lipid dan menjadi sel busa, yang ditandai dengan sitoplasma yang dipenuhi oleh droplet lemak. Saat fraksi lemak berevolusi menjadi lesi aterosklerotik, selsel otot polos bermigrasi dari lapisan media melalui membran elastis internal dan menumpuk pada lapisan intima. ${ }^{14}$

Penelitian ini memiliki beberapa keterbatasan. Pertama, desain studi ini adalah cross-sectional, sehingga tidak dapat menentukan hubungan temporal sebab-akibat antara tingginya kadar kolesterol total dengan tingginya tekanan darah. Kedua, karena pengambilan sampel dengan cara consecutive non-random sampling sehingga sampel tidak mewakili secara pasti distribusi faktorfaktor risiko dan penyakit di populasi di wilayah kerja Puskesmas Kelurahan Joglo II; oleh sebab itu, aplikasi hasil penelitian ini kepada populasi tersebut harus dilakukan dalam batasan tersebut. Ketiga, status menopause yang juga merupakan salah satu faktor risiko hipertensi tidak kami teliti sehingga memungkinkan terjadinya bias perancu.

\section{Kesimpulan}

Penelitian ini membuktikan hubungan yang bermakna secara statistik antara kadar kolesterol total dengan tekanan darah sistolik (nilai $\mathrm{p}=0,005$ ) maupun diastolik (nilai $\mathrm{p}=0,002$ ). Dibutuhkan penelitian lebih lanjut dengan desain lain seperti kasus-kelola atau kohort untuk mengetahui dengan pasti pengaruh kadar kolesterol total pada tekanan darah, khususnya di masyarakat Indonesia.
Pada kadar kolesterol total yang dipertahankan $<200$ $\mathrm{mg} / \mathrm{dL}$, didapatkan tekanan darah sistolik dan diastolik berada pada kisaran $<127 / 84 \mathrm{mmHg}$. Oleh sebab itu, pemeriksaan kadar kolesterol total dilakukan secara rutin.

\section{Saran}

Pemantauan kadar kolesterol total disarankan untuk tetap dalam batas normal $(<200 \mathrm{mg} / \mathrm{dL})$, sehingga diharapkan dapat mencegah risiko tekanan darah tinggi.

\section{Ucapan Terima Kasih}

Peneliti mengucapkan terima kasih kepada pimpinan serta seluruh staf Puskesmas Kelurahan Joglo II Jakarta Barat atas bantuannya dalam pengumpulan data penelitian ini.

\section{Daftar Pustaka}

1. Madhur MS, Riaz K, Dreisbach AW, Harrison DG. Hypertension [serial on the internet]. New York: Medscape; 2011 [cited 2011 June 17]. Available from: http://emedicine.medscape.com/article/241381overview

2. Minh HV, Byass P, Chuc NTK, Wall S. Gender differences in prevalence and socioeconomic determinants of hypertension: findings from the WHO STEPs survey in a rural community of Vietnam. J Hum Hyper [serial on the internet]. 2006; 20: 109-15 [cited 2011 June 17]. Available from: http://www.nature.com/jhh/journal/v20/n2/full/ 1001942a.html

3. Singh RB, Suh IL, Singh VP, Chaithiraphan, Laothavorn P, Sy RG, et al. Hypertension and stroke in Asia: prevalence, control and strategies in developing countries for prevention. J Hum Hyper [serial on the internet]. 2000; 14 (10/11): 749-63 [cited 2011 June 17]. Available from: http://www.nature.com/jhh/journal/v14/n10/abs/100105 7a.html

4. Pusat Komunikasi Publik Sekretariat Jenderal Departemen Kesehatan Republik Indonesia. Hipertensi penyebab kematian nomor tiga. Press release Kementrian Kesehatan Republik Indonesia [online]. Jakarta: Kementrian Kesehatan Republik Indonesia; 2009 [diakses tanggal 17 Juni 2011]. Available from: http://www.depkes.go.id /index.php/berita/press-release/810-hipertansi-penyebab-kematian-nomor-tiga.html

5. Pusat Komunikasi Publik Sekretariat Jenderal Departemen Kesehatan Republik Indonesia. Hipertensi faktor risiko utama penyakit kardiovaskular. Press release Kementrian Kesehatan Republik Indonesia[online]. Jakarta: Kementrian Kesehatan Republik Indonesia; 2009 [diakses tanggal 27 Juni 2011]. Diunduh dalam: http://www.depkes.go.id/index.php/berita/press-release/157-hipertensi-faktor-risiko utamapenyakit-kardiovaskular.html

6. Akuyam S, Aghogho U, Aliyu I, Bakari A. Serum total cholesterol in hypertensive Northern Nigerians. Int J of Med and Med Sci [serial on the internet]. 2009; 1(3): 73-74 [cited 2011 June 13]. Available from: http://academicjournals.org/article/article1379078366_Akuyam $\% 20$ et $\% 20$ al.pdf

7. Chehrei A, Sadrnia A, Samanjanpour P, Soltani P, Mashayekhim N. Lipid profile cutoff values for predicting hypertension in an Iranian population (ROC curve analysis). Med Sci Monit [serial on the internet]. 2007; 13(2): 100-4 [cited 2011 September 1]. Available from: http://www.ncbi.nlm.nih. gov/pubmed/? term=Chehrei+A+Lipid+pro- 
file+cutoff+values+predicting+hypertension+Iranian+population.

8. Pan J, Li N, Yan Z. The relationship between serum total cholesterol level and blood pressure among male Kazakhs. J Nongken Med [serial on internet]. 2008; 3: 22 [cited 2011 August 15]. Available from: http://en.cnki.com.cn/Article_en/CJFDTOTAL-NKYX2008 03022.htm

9. Hjerman I, Helgeland A, Holme I, Larsen P. The association between blood pressure and serum cholesterol in healthy men: the Oslo study. J Epidemiol Comm Health [serial on internet]. 1978; 32: 117-23 [cited 2011 September 1]. Available from: http://www.ncbi.nlm.nih.gov/ pmc/articles/PMC1060929/pdf/jepicomh2000 02-1046.pdf.

10. Pincherle G, Robinson D. Mean blood pressure and its relation to other factors determined at a routine executive health examination. J Chronic Dis [serial on internet]. 1974; 27: 245-60 [cited 2011 September 1]. Available from: http://www.sciencedirect.com/science/article/pii/0021968174900496.

11. Bulpitt C, Charles H, Everitt M. The relationship between blood pres- sure andbiochemical risk factors in a general population. British Med J [serial on internet]. 1976; 30: 158-162 [cited 2011 September 1]. Available at: http://www.ncbi.nlm.nih.gov/pmc/arti cles/PMC478957/pdf/briprevsmed00023-0020.pdf

12. Salonen J, Puska P. Is there an Association between serum cholesterol and blood pressure changes? Acta Med Scand [serial on internet]. 1983; 214: 49-54 [cited 2011 September 1]. Available at: http://onlinelibrary.wiley.com/doi/10.1111/j.0954-6820.1983.tb08569.x/full.

13. Maulana I. Hubungan kadar kolesterol total dengan hipertensi pada lansia di wilayah kerja puskesmas Sungai Besar Banjarbaru [online]. Al Ulum. 2008 ; 36(2): 11-5 [cited 2011 June 15]. Available from: http:// jurnal.pdii.lipi.go.id/admin/jurnal/362081115.pdf.

14. Libby P. The pathogenesis, prevention, and treatment of atherosclerosis. In: Fauci AS, Braunwald E, Kasper DL, Hauser SL, Longo DL, Jameson JL, et al., editors. Harrison's principles of internal medicine. 17th ed. New York: McGraw Hill; 2008. p. 1501-3. 